\title{
obituary
}

\section{W. W. Bishop}

Dr. Walter William Bishop, Head of the Department of Geology at Queen Mary College, University of London, died suddenly at his home on 19 February 1977, at the age of 45 .

A native son of Birmingham, he graduated from the University there in 1952 with an honours degree in geography followed by a Certificate in Education. However, his interests turned towards geology and it was in this field that he received his Ph.D. degree at Birmingham in 1956. He went immediately to Africa as geologist with the Uganda Geological Survey and, through contacts with $\mathrm{E}$. J. Wayland and L. S. B. I eakey, became involved with studics of Pleistocene deposits and the geomorphological evolution of the region.

By 1959 he had demonstrated the natural origin of the supposed "Kafuan" culture and provided evidence for morphological and tectonic control of the events that had led to the erection of a rigid climatic framework that now seemed insupportable. The fossil-bearing Miocene sediments also attracted his attention and his first African paper was a brief account of Miocene mammals from Napak. Further field work in Uganda and Kenya later led him to realise the important genetic relationships that existed between the Miocene fossil deposits and the volcanic cones throughout the region.

Thus, within three years of his arrival, was established the pattern of his many important contributions on the stratigraphy, geomorphology and volcanics of the Tertiary and Quaternary in East Africa, as well as his fruitful association with archaeologists, anthropologists and palaeontologists concerned with mammalian and hominoid evolution.

In 1959 he went to the University of Glasgow as Assistant Lecturer in Geology and Assistant Curator at the Hunterian Museum, but after three years returned to East Africa as Director of the Uganda Museum in Kampala and Lecturer in Geology at Makerere College, University of East Africa. These years were very productive and Bill Bishop soon became the recognised authority on the Tertiary and Quaternary of the region. At the Museum he was responsible for several new developments, such as the establishment of a Museum Education
Service. He organised a number of expeditions, including the Baker Centenary Expedition (1963) to study the geomorphological evolution of the Lake Albert rift valley, which led to a new picture of the stratigraphy and to important fossil collections from the Pliocene-Pleistocene Kaiso Beds.

The prospect of a teaching position tempted him back to London in 1965 as Lecturer in Geology at Bedford College, where Professor Basil King was already interested in research on the volcanics of the rift valley and directed the East Africa Geological Research Unit. This unit undertook 'responsibility for systematic geological mapping in the Lake Baringo basin, where important sedimentary deposits were found sandwiched within a long volcanic sequence; these beds provided valuable fossil material bridging a former gap between the middle Miocene and the late Pliocene. Radiometric dating was aplied to the entire Miocene succession, thus establishing for the first time a good chronology for the faunas.

After moving to Queen Mary College in 1974, Professor Bishop continued his East African field work, partly in association with Richard Leakey, but also began work in Pakistan where a group from Yale University was re-examining the Miocene-Pliocene Siwalik sediments and their critical hominoid fossils. He was invited to become Director of the Peabody Museum at Yale and his death occurred only a few months before he was due to take up this appointment. Not long before he had been honoured by the award of the Prestwich Medal of the Geological Society of London in recognition of the outstanding contributions that had made him "a world leader in the very active field of African geology."

Always a co-operative, enthusiastic and helpful person, Bill Bishop was deeply involved in local, national and international bodies ranging from student societies to the Presidency of the INQUA Sub-Commission for Quaternary Stratigraphy of Africa. He served the Geological Society of London as a Council member, as its Secretary, and as Scientific Editor of the Journal, doing a great deal to build un both the Society and its publication. He was joint organiser of two symposia sponsored by the Wenner-Gren Foundation for Anthropological Research and edited the two books that have become standard references for the time scale of hominoid evolution. In 1975 he organised a highly successful three day symposium on a similar theme for the Geological Society of London, as yet unpublished.

Dr Bishop was a lively and attractive speaker and was guest lecturer at many institutions. At meetings, his tact and insight smoothed over potential conflicts and his humour was infectious. His performances in amateur dramatics and his admirable voice in light opera will long be remembered, as well as the witty ditties with which he sometimes enlivened scientific meetings. His death is not only a great loss to science but also a severe personal loss to his many friends and colleagues throughout the world. His happy family life with his wife and two sons did much to sustain him in his busy existence and his love of natural history remains imprinted in them as his science does in his students and his colleagues.

H. B. S Cooke

\section{J. A. V. Butler}

John Alfred Valentine Butler, F.R.S., Emeritus Professor of Physical Chemistry at the University of London, died on 16th July after a short illness.

'J. A. V.', as his friends knew him, was born on St. Valentine's day in 1899. His early education was at Cheltenham Grammar School, and he took his first degree in chemistry at Birmingham University. After a short stay at the University College of Swansea he spent 12 years as a lecturer at the University of Edinburgh. Although he was a physical chemist, we know that during this period he came into contact with Edgar Stedman who, in the late thirties, was beginning his work on the composition of the cell nucleus. From the few comments we heard J.A.V. make about his relationship with Edgar Stedman at that time, we gathered that it was not always harmonious. Nevertheless an obvious interest in the chemistry of the cell nucleus was planted at that time, and was to emerge later.

In 1939 a Rockefeller fellowship took him to the U.S.A. where he also served as an executive officer in the British Commonwealth Scientific Office in Washington.

In 1946 he returned to England to 
work at the Courtauld Institute of Biochemistry in London for three years, and in 1949 came to the Chester Beatty Research Institute to apply his physical chemical knowledge and techniques to the study of DNA. This began an interesting and exciting 17 years, during which he studied many aspects of the chemistry of the components of the cell nucleus.

It was in 1953 that I first met J.A.V., and being a very junior member of the technical staff at that time I had little to do with him in an official capacity. However, within six months he was telling me in considerable detail why my geraniums were dying, and the need for repotting them at frequent intervals. Although I believe he was basically a shy man, he was friendly with all members of his staff, and never hesitated to allow the students a day off for the Varsity Rugby match at Twickenham.

He will be remembered also, I am sure, by his friends at the Institute, for his absent-mindedness. I have seen him return from an academic board meeting with two hats, one on his head and one in his hand, hotly pursued by the rightful owner of the second hat. On another occasion. deep in conversation with a colleague in a café. he complained about not receiving any change, only to find it in his coffee when he stirred it!

The stories about J.A.V. are legion. His lack of pens and pencils, the gunfight he caused in Chicago by losing his brief-case, and his very, very long pauses on the telephone before he answered "Butler here". He was in all ways the epitome of the "absent-minded professor".

We will also remember well his method of crossing the Fulham Road. Head down, deep in thought, shoulders slightly bent, straight across, ignoring all traffic. A screech of car brakes was often the sign that J.A.V. was crossing the road.

He was however, clear and precise about his research. Although he began by applying his knowledge of physical chemistry to the structure of DNA, he soon became interested in the wider aspects of DNA control and his interests lead him into the fields of DNA synthesis, RNA synthesis and the functions of the chromosomal proteins. This was, of course, in the fifties when molecular biology was in its infancy, and most people chose to forget that DNA was associated with an equal amount of protein.

$\mathrm{He}$ felt that the best strategic approach to the cancer problem was to understand the fundamental aspects of gene control and he directed his department to this end. However, he was keenly aware that this was a long term approach and once confided to me that he was sad we could do so little of immediate value.

Apart from his work within the Institute, his scientific interests were wide and varied. He edited Progress in Biophysics and Molecular Biology for over 25 years and his publications, apart from his research work, varied from a text book on chemical thermodynamics to a very successful series of books, written for the layman, on various aspects of cell and molecular biology.

$\mathrm{He}$ was appointed to the newlyestablished chair of Physical Chemistry at the Institute in 1952, and was elected a Fellow of the Royal Society in 1956.

After his retirement in 1966 he still took an active interest in the work and was often to be seen at scientific meetings. He frequently called in to see us and to hear about the latest work. His last visit was early this year, when true to form he left his brief-case in my room, fortunately remembering it before he left the building.

$\mathrm{He}$ was widely read, keenly interested in the arts and an amateur painter of some merit.

He married Margaret Lois Hope in 1929 , and as all his friends who visited his home knew well, he had a very happy and contented domestic life. His three children, two sons and one daughter, all followed his lead and have made careers in various other scientific disciplines. E. W. Johns

\section{F. H. Ludlam}

F. H. Ludlam, Professor of Meteorology and Head of the Atmospheric Physics Group at Imperial College, London, died on 3 June 1977 aged 57 years. Frank Ludlam studied clouds. His descriptions of the movement of air and water vapour and rain through clouds were so intense and graphic that one began to suspect that he had some supernatural power to actually identify himself with a cloud.

He saw so much. He would come into a lecture with perhaps 20 slides then spend all his time talking about the first, frequently drawing back from removing it because some new feature had just caught his attention.

Having made fundamental contributions to the microphysics of clouds during the 1940's while working at the Meteorological Office, he moved to Imperial College and away from the study of the details of processes towards the study of the organisation and dynamical structure of clouds. This philosophy culminated in his now classical description of the motion of air in severe thunderstorms. Like all grand ideas this one could, in retrospect, have been seen coming for years, but Ludlam had it. He discarded what he called 'the haystack theories' of storms. These were illustrated by diagrams, and thinking, with arrows all over the place. He replaced it by a streamline theory showing where the air and water came from and where it went to. He took a certain delight in the fact that, working on a tiny budget, he made a very satisfying advance in a subject of great economic importance.

Subsequently his interest shifted progressively to phenomena of larger scale. For his inaugural lecture in 1966 he showed that weather systems could be seen in a new perspective by examining them relative to axes moving with the system: again almost identifying himself with the phenomenon. This was his way of using the abstract concepts of pattern movement as distinct from pattern development developed by his penetrating contemporary, Eady. But whereas Eady's concepts were based on distinction of mechanism and arose from mathematical elegance and clarity, Ludlam made them lead to pictorial and functional beauty.

No man showed better the false distinction between artist and scientist. To him good science made a pleasing picture. He delighted in the impish gesture. Few present at a lecture to the Royal Meteorological Society (on threedimensional data analysis) will forget the impact made when he projected a slide of a Rodin nude (very female) in the middle of a masterly description of the techniques of synoptic analysis.

In his magnum opus entitled Cloud Physics to be published by the Pennsylvania State University Press, he summarises his views on atmospheric phenomena from a few microns in scale to $40,000 \mathrm{~km}$. He was concerned with the notion that conventional physicists, wedded to the controlled experiment, did not understand the essence of meteorology as he saw it. What he did see was an immensely elaborate system with complex feedback. The essence was the feedback and the uncontrollability of the meteorological experiment. He was the privileged onlooker. He even took lightly some of his beautiful and fundamental work on cloud microphysics and said it did not really matter if it were wrong: the atmosphere would find some way of fulfilling a more over-riding purpose whatever the details of the processes.

Such an integrating philosophy is likely to be fundamental for the study of complex systems like the atmosphere and we are privileged to have had so talented an exponent of it.

John Green 